\title{
Sweet Suburbia and the Bustling City
}

\author{
DIEGO BONELLI
}

\begin{abstract}
This paper focuses on the representation of Wellington in New Zealand tourism films in the decades preceding the establishment of the National Film Unit (NFU) in 1941. While critically engaging with current discourses about early New Zealand film production, New Zealand film history, New Zealand human geography and the cinematic city, it performs the textual analysis of eight case studies also examining archival materials related to their production, circulation and reception. This article aims to demonstrate how the cinematic depiction of New Zealand's capital city in the analysed time frame was a complex and multi-layered process driven and characterised by the coexistence and intertwining of tourism marketing, national publicity and colonial agenda.
\end{abstract}

\section{Introduction}

An overview of New Zealand film production during the early decades of the twentieth century highlights its strong links with the local tourism industry. An analysis of tourism films produced and released in New Zealand in this period shows the country's effort to present and promote itself as both an appealing tourist destination and an attractive land for new settlers. In fact, since the start of government involvement, the tourist promotional effort has been systematic. ${ }^{1}$ In the early decades of the twentieth century, tourist images of New Zealand were "part of a wider corpus of colonial propaganda encouraging the emigration needed to boost what was seen by many to be a shrinking New Zealand population."

The Government Publicity Office (GPO), a government-led film production company, was in charge of New Zealand's tourism promotion between 1923 and $1941 .{ }^{3}$ Over these two decades, the representation of land, landscape and national locations gradually increased and national film production increasingly conveyed a sense of national pride and self-awareness. The circulation and screening of New Zealand tourism films and tourist material within New Zealand itself, Australia and Europe was a consolidated and widespread practice in the first four decades of the last century, to the point that, according to Leotta, "the New Zealand governments of the first half of the twentieth century were, in fact, pioneers in the use of film as a means of national publicity."

Before the emergence and spread of photography and film, the production and circulation of painted landscapes played an important role in the establishment of settler societies; New Zealand was no exception. ${ }^{5}$ Through the lens of the colonial gaze, images depicting colonial landscapes became "as important as words." Pratt, by a multilayered complexity and a density of meaning. ${ }^{7}$ Early New Zealand publicity closely embodied what Byrnes defined as "the colonial utilitarian attitude towards land" reflected in the strong visual focus on the land's "commercial potential and value." A large number of nineteenth-century paintings displayed views taken from high standpoints, a colonial pictorial leitmotiv; this specific mode of seeing and representing the landscape encouraged viewers and potential settlers to take possession of the land. ${ }^{9}$ This visual and ideological convention was soon borrowed by photography and, over the second half of the 
nineteenth century, similarly played a crucial role in the spread and promotion of New Zealand landscapes. According to Hancox,

the modern history of New Zealand . . coincides almost exactly with the history of photography. This country is visually unique within Western culture. ... Photography has ultimately been New Zealand's most important art of colonisation. Furthermore, photography has, of all the arts, been the principal mode of seeing and documenting the landscape. ${ }^{10}$

From the early twentieth century, New Zealand film in turn extensively relied on visual tropes and conventions borrowed from painting and photograph. ${ }^{11}$

Studies of the representation of landscape have emphasised its cultural and symbolic nature, highlighting the link between the emergence of the idea of landscape and the rise of mass tourism and visual consumption of places during the first half of the nineteenth century. ${ }^{12}$ In the GPO era, attempts to circulate images of New Zealand landscapes overseas were matched by the necessity to promote the country to domestic audiences. Landscapes- "constructs of imagination projected onto wood and water and rock"-played a crucial role in shaping nationalism and national identities during the nineteenth and twentieth centuries. ${ }^{13}$ The manland relationship as well as the process of constructing national identities implied the perception and the identification of a landscape's uniqueness and distinctiveness. ${ }^{14}$ In New Zealand native landscapes, flora and fauna soon became the core of this creative process. ${ }^{15}$

The role played by film in forging nationhood closely recalls Anderson's words: "often in the 'nation-building' policies of the new states . . . one sees a systematic, even Machiavellian instilling of nationalist ideology through the mass-media."16 In fact, the role played by the widespread domestic circulation of GPO films and tourism films, and more specifically by iconic early films such as Glorious New Zealand and Romantic New Zealand, was important in shaping a sense of national community and national identity. ${ }^{17}$ Leotta points out that "the national New Zealand spirit was meant to be shaped, according to the Tourist and Publicity Department, through the very consumption of the country's scenic views." 18

The relationship between extra-urban landscapes, cultural identity and colonial promotion in New Zealand has been extensively analysed. However, New Zealand cities also played an important role in shaping the country's early tourism marketing and colonial agenda. In early New Zealand tourism films, the depiction of New Zealanders' everyday life links an otherwise timeless collection of scenic gems to time and history, and, more specifically, to the contemporary Western world. ${ }^{19}$ In national tourism film production the modern facilities and means of transportation of New Zealand cities are regularly in the foreground; the emphasis on Wellington's quality of life is meant to address both potential tourists and settlers. Appealing urban and suburban landscapes, multiple opportunities for practising healthy outdoor activities, an excellent transport system, attractive residential areas, modern architecture, appealing nightlife, good job opportunities: all the themes and narratives emerging from the textual analysis of the case studies are shaped around the needs and goals of national publicity.

Over the 1920s and 1930s the GPO released six films depicting Wellington. ${ }^{20}$ Besides engaging with the existing academic literature and with archival documents related to early governmentled New Zealand film production, this study focuses on the textual analysis of these six films, adding case studies of one film from the pre-GPO era and of one by another production company, Sound Film Productions. They are, in chronological order: Wellington and Assorted 
Scenes, by Sydney Benjamin Taylor, a cameraman working for the Department of Agriculture, Industries and Commerce; Wellington Capital City of New Zealand; Deep Harbour: The Port of Wellington; Wellington Sunshine Sands; The Maritime City; Romantic New Zealand, all by the GPO; Around Port Nicholson, by Sound Film Productions, a private New Zealand-based film production company; and Glimpses of New Zealand: Wellington New Zealand's Capital City, again by the GPO. ${ }^{21}$

\section{A Rising Tourism Industry}

With its great distance from the rest of the world (except for Australia), slowness of sea transport, rugged terrain, changeable and unstable weather, and lack of domestic transport routes and facilities, the newly born New Zealand tourism industry had to overcome a number of difficult challenges during the last decades of the nineteenth and the first decades of the twentieth century. ${ }^{22}$

Four fundamental key moments and turning points can be identified in New Zealand early tourism history. The first of these was the opening of the Suez Canal in 1869, which reduced considerably the length of the journey from Europe to New Zealand by avoiding the circumnavigation of the African continent, and consequently increased the number of tourists arriving by ship. A second important factor that led to new perspectives and a substantial growth in domestic tourism in the 1920s and 1930s was the improvement of the national road infrastructure and the consequent spread of vehicles for private and public transportation. ${ }^{23}$ The third key moment corresponded with the use of film as a means of tourist promotion. If the importance of photography is widely recognised in the context of New Zealand's early promotion, from the 1920 onwards, as a consequence of the establishment of government organisations such as the GPO in 1921 and the National Film Unit (NFU) in 1941, film became, as demonstrated by the large amount of tourism films produced in New Zealand, the most important medium to promote the country both nationwide and overseas. ${ }^{24}$ The fourth milestone corresponded with the government's systematic involvement in the national tourism industry, that started in 1901, when New Zealand became the first country to establish a government department dedicated specifically to tourism, the Department of Tourist and Health Resorts. ${ }^{25}$ This department was involved in the promotion and advertisement of the country, in the construction and management of important hotels and resorts in the main tourist locations, and as well in the creation of the first government-funded national tourism campaigns.

The early decades of the twentieth century were characterised by numerous and lively parliamentary debates about the promotion of New Zealand. The newly born Department of Tourist and Health Resorts employed a variety of techniques to promote the country. ${ }^{26}$ Besides the distribution of promotional material overseas and the organization of fairs and exhibitions in New Zealand, the government opened "a number of offices abroad and throughout New Zealand to assist tourists and prospective investors and settlers." 27

A 1924 parliamentary speech well exemplifies the common viewpoint concerning New Zealand tourism promotion at this time. According to the parliamentary chronicle of The Evening Post, the minister of commerce H. D. Bennett reminded the ministers of the immense volume of tourist traffic in the world, and the amount of money it represented in expenditure. New Zealand was entitled to a greater share of the patronage of these travellers, but could not expect it until the country was better advertised. ${ }^{28}$ 


\section{Coastal Playgrounds and Suburban Sprawl}

In GPO tourism films, New Zealand's landscape is displayed as a reassuring, domesticated and non-threatening space, a playground for middle-class urban masses where wildlife often appears to be a nice frame and an appealing background for all sorts of sporting and leisure activities. ${ }^{29}$ A remarkable number of early tourism/promotional films released in the early decades of the twentieth century depict the Māori world; race relations between Māori and Pākehā are used as a vehicle for tourist promotion. ${ }^{30}$ However, even though the representation of national landscapes and Māoridom took the lion share, the depiction of New Zealand urban areas was not infrequent. The number of tourism films dealing with urban areas is not large in relation to the overall tourism film production for this period, yet most have survived until today. Alongside the constant representation of the best-known urban tourist spots-the Cathedral, Cathedral Square and the Avon River in Christchurch, neogothic Otago University's buildings and the railway station in Dunedin, Queen Street, the waterfront and the skyline in Auckland-and a certain taste for stereotyped and conventional description shaped around their cultural heritage or their climatic characteristics-"English Christchurch," "Scottish Dunedin," "Sunny Napier" and "Sunny Auckland"- the depiction of New Zealand urban areas displays some specific patterns. ${ }^{31}$ First of all, suburbia play a very important role in urban promotion. Indeed, the celebration of the suburban sprawl and suburban single-detached housing features in the vast majority of New Zealand urban tourism films. Coastal areas and more specifically beaches are similarly depicted as a purely suburban space, as an integral, constitutive aspect of the suburban landscape and lifestyle and as a recurring cornerstone of urban tourist promotion. ${ }^{32}$ The representation and celebration of urban modernity and efficiency, urban busy life, means of transportation and hectic traffic is another recurring theme in GPO urban tourism films. In the first decades of the twentieth century, Wellington isamongst all New Zealand cities-the most frequently represented in tourism film. ${ }^{33}$

Recent research in sociology and in human geography has extensively highlighted the cultural relevance of the New Zealand beach. ${ }^{34}$ In fact, public urban beaches and urban coastal areas have been for a long time the place for leisure outdoor activities par excellence in Wellington. While briefly focusing on the capital city of New Zealand, Romantic New Zealand, one of the best known GPO productions of the 1930s, dwells upon its sandy beaches. The narrator highlights "its forty-five miles of coastline" and "abundance of sheltered bays," while people of all ages are portrayed engaging in beach and sea activities. The importance of coastline and beaches in the tourist representation of Wellington is also evident in the silent film Sunshine Sands: Wellington's Holiday Land, a visual celebration of suburban Wellington that depicts a day trip to a suburban beach, with different stages precisely and joyfully described by intertitles. The trans-harbour ferry carries beachgoers from the city centre to suburban "Day's Bay sunshine sands." After showing images from the harbour crossing and the landing of Wellingtonians on a crowded beach, this GPO film dwells on scenes of beach life: families and people of all ages are portrayed at leisure. Inter-titles go hand in hand with images. All the usual seaside sports and activities are featured: canoeing, rowing, sailing, swimming, sunbathing, diving. However, Day's Bay offers tourists and visitors other recreational options: tennis courts and tennis players are depicted as well as the Pavilion, a tourist infrastructure described in subtitles as a "refreshment centre" featuring facilities such as cafés, bars and restaurants surrounded by an extensive park. At sunset, the ferry carries tourists back to the city. Wellington's suburban coast and beaches seem to be the ideal location for a short holiday, an ideal tourism product for both tourists' and city dwellers' consumption. 
The beach's proximity to the city centre suggests mobility, easy accessibility and easy escape from hectic city life. It is easily reached by modern means of transportation (either ferry or car; a number of parked cars are visible on the beach's fringe), it offers all recreational facilities, and it is represented as a playground for urban masses in the same way as some other New Zealand natural attractions-Mount Cook, Mount Tongariro and Rotorua-are depicted in these early decades of the twentieth century. Wellington and Assorted Scenes, a collection of scenes recorded by Sydney Taylor during his time as a cameraman for the Department of Agriculture, Industries and Commerce, similarly dwells upon moments of suburban beach leisure at Lyall Bay. However, unlike in Sunshine Sands: Wellington's Holiday Land, the representation of the suburban beach does not seem to be driven by any particular agenda. The 1930 GPO film displayed Day's Bay as a profusion of sport/leisure attractions, particularly focusing on its easy accessibility from the city centre; while Wellington and Assorted Scenes shows no means of transportation, the number of men wearing street clothes, suits and hats and of women in long dresses suggests a proximity to and an easy accessibility from the city centre. Moreover, the initial long take, besides lingering upon the beach, also features parts of the suburb: it is therefore clear that Lyall Bay and its beach are on the suburban fringe of the city. This film does not provide any evidence of organised tourism or tourism facilities, except for changing sheds. Rather than focusing on the different leisure attractions and the tourist potential of the location, this film captures different types of people and different types of faces. Children are depicted through both long and medium shots playing games on the sand while groups of adults sit and chat next to them; a medium shot shows groups of young boys in bathing suits smiling at the camera; young girls in long skirts dip their feet in the sea, while only a few people dare to swim. Here, suburban beachgoing seems to be a joyful, egalitarian ritual that brings together people of all ages; its representation is mainly related to the description and promotion of a relaxed, informal, healthy lifestyle.

Not only suburban beaches, but also the coastal areas of Wellington's city centre are depicted as a consumer product for tourists and city dwellers. Wellington and Assorted Scenes features scenes from Te Aro Baths and Oriental Parade. After briefly focusing on young Wellingtonians diving and swimming at Te Aro Baths before an urban background, a long panoramic shot shows boats moored at Clyde Quay Marina. Similarly, Wellington, Capital City of New Zealand displays boats and boat sheds at Oriental Parade and people rowing at Clyde Quay Marina as an important and integral part of the urban landscape and lifestyle.

Deep Harbour: The Port of Wellington (GPO) and Around Port Nicholson (Sound Film Productions) briefly focus on two beaches at the extreme fringe of the city. The former features an aerial view of Breaker Bay beach on a day of rough seas: inhospitable, empty, apparently isolated and far away from the city yet surrounded by groups of scattered suburban houses; the latter portrays Red Rocks invaded by a flock of sheep. Here the suburban beach is no longer a playground for city dwellers and is not related to the tourism industry, tourist rituals or a healthy lifestyle; on the contrary, it represents a fringe between the inhabitable and the uninhabitable, the encounter between the urban and the extra-urban (be it rural or marine space). Even though in these two case studies the beach displays its liminal geographic and cultural nature, it is still an integral part of Wellington and, in some sense, inseparable from the representation of the city itself.

In the fields of sociology and human geography, the beach is generally defined and described as a liminal space. ${ }^{35}$ According to Shields, experiencing the beach implies a condition he defines as "in between-ness," that is, a loss of social coordinates, and, in his words, "a liberation 
from the regimes of normative practices and performance codes of mundane life because of its interstitial nature." 36 The somehow ambiguous and transitional nature of the beach is similarly highlighted by Matthewman, who stresses its cultural and social importance as a "site of escape, leisure and identity formation." 37

The beach as a geographic and cultural space is of great importance in New Zealand. The beach typically plays different - even diametrically opposed - roles in Maori and Pakeha cultures. According to Turner, "Pākehā truly find themselves at the beach." ${ }^{38}$ As he highlights, the beach as a place for leisure is a concept related to contemporary, European colonial culture; Pākehā New Zealanders see it as a place for regeneration, a circumscribed and ahistorical leisure space, whereas for Māori the beach has always essentially been a place of work and sustenance. Both Leotta and Matthewman examine the role and importance of the beach in national cultural identity, drawing similar conclusions. The former, while analysing the representation of Karekare Beach in one of the most iconic New Zealand feature films-Jane Campion's The Piano-identifies it as the quintessential and most touristically appealing New Zealand beach: in his words, it is "empty, wild and untamed." 39 The latter points out the contrast between the perception of the beach in Australian and New Zealand popular culture. According to Matthewman, Australians tend to prefer urban, highly urbanised and commercialised beaches - for instance Sydney's Bondi Beach — whereas the ideal and most loved New Zealand beach - Piha - is out of the way, dangerous and wild. ${ }^{40}$

In fact, the cultural perception of the beach in New Zealand seems to have changed throughout time. Its representation as a liminal, wild, natural and untamed space appears to be quite recent, featuring in worldwide tourism campaigns such as $100 \%$ Pure New Zealand, describing and promoting the country as pure and uncontaminated. However, for decades, at least for the first four decades of the twentieth century, the beach in New Zealand tourism/promotional film has been presented as a reassuring place. As shown in the surviving tourism films from the 1910s, 1920s and 1930s, rather than an extra-urban, far-away, wild and lonely space, the beach is at the suburban fringe of a city or town, a highly domesticated and comfortable place for urban holidaymakers and leisure seekers. This seems to reflect a more general coeval attitude in tourist national promotion. Early twentieth-century tourism films depict New Zealand's natural environment in an inviting and reassuring way: New Zealand is an interesting destination for both lovers of nature and outdoor activities, and for potential settlers.

The depiction of the beach as a suburban space and integral part of Wellington's urban context seems to go hand in hand with the promotion of a specific lifestyle. The necessity of separating workplaces from residential areas and work from life-according to Williams the main reason for the spread and success of suburban areas and suburban lifestyle in the Western worldfinds in suburban beaches its full and more visible expression. ${ }^{41}$ From this point of view, early twentieth-century New Zealand beach-going and, more generally, the New Zealand suburban beach as the privileged, egalitarian and democratised meeting point for urban masses, directly linked through the means of transportation to the capitalist system but at the same time evidently connected to an idea of newness and physical and moral renewal, assumes an unexpected and so far unexplored importance in the definition of national cultural identity.

The visual celebration of the suburban sprawl is the other mode through which Wellington's suburban space is put on display in tourism films. One film in particular, Sunshine Sands: Wellington's Holiday Land, dwells on suburbs and makes them protagonists. Inter-titles describe them as "climbing" and the hills surrounding the harbour as "thickly clustered with 
red roofed dwellings." The film opens with scenes of a hilly suburb-seemingly Brooklynoverlooking the whole harbour. The panoramic view captures dwellings surrounded by lush vegetation, a passerby calmly strolling down a footpath, and a tram gradually approaching from downtown. These scenes convey an overall impression of brightness, beauty, wealth, and healthiness, while the tram suggests a proximity to the city centre. At the same time, the suburb also appears distant from central Wellington-the city centre and the harbour are visible only in a faraway background, through the houses and the lush vegetation. The same film depicts Day's Bay, in the Eastbourne area, in a similar way. This suburban area seems to be even more affluent than the previous one and more scenically attractive: it overlooks a bay and a beach, portrayed through an aerial shot, and houses are literally immersed in greenery and built, according to the inter-titles, on "sunlit slopes."

However, rather than focusing on specific Wellington suburbs, tourism/promotional films often tend to linger visually on urban expansion and suburban sprawl. Therefore, what appears important in promotion is not just the focus on particular practical, potentially attractive aspects of Wellington suburbs - their good standards of life, their healthy housing, their greenery, their panoramic location and good transportation systems-but also on a more abstract idea of incessant urban growth and economic, social and demographic advancement, as portrayed through recurring bird's-eye views of expanding city limits. Wellington, Capital City of New Zealand features a long bird's-eye view from the northern to the southern suburbs, which includes a number of barely recognizable hilly and flat suburban areas. A similar bird's-eye view of coastal suburbs is seen in Deep Harbour: The Port of Wellington and in Romantic New Zealand.

Ultimately, the presence and appealing representation of suburban Wellington appears to be influenced by both tourist and colonial promotion. On the one hand, Wellington is attractive for potential tourists since it features a number of scenically appealing hilly suburbs, beaches and coastal locations. On the other, Wellington suburbia embodies the promise of moral and physical regeneration for potential new settlers.

\section{Recurring Themes and Ideological Roots in the Celebration of Wellington's Urban Modernity}

Alongside the depiction and celebration of suburban space and suburban lifestyle, early tourism films about Wellington frequently feature images and scenes of urban mobility, work and architectural verticality. The representation of these three recurring themes appears to be specifically linked to the depiction of Wellington's central, most productive and non-residential areas.

After an initial aerial long take on Wellington harbour, The Maritime City, a nine-minute 1930 GPO film, dwells upon images of both urban and ship transport, its representation of urban mobility shifting from naturalistic to stylised. Initially, the camera is placed right in the middle of Lambton Quay, capturing the incessant coming and going of trams, cars and pedestrians. This mimetic approach - the camera is an invisible, immobile eye focused on urban lifeconveys a lively and realistic impression of Wellington's hectic urban life. The subsequent two shots are taken from a moving tram, providing viewers with the impression of travelling for one minute along busy Lambton Quay, identifying themselves with the experience of urban mobility. After dwelling for more than one minute on Lambton Quay, the film lingers on Courtenay Place, according to the subtitles the "centre of the spreading tramway system." Initially, the camera is - once again - placed in the middle of the street to capture the bustling 
city traffic: the takes are accelerated, conveying the dynamism and vitality of a thriving environment. Wellington Capital City of New Zealand (GPO, 1925) dedicates one minute out of six and a half to the depiction of central city traffic. The camera is placed in the middle of the action; trams and their passengers are the protagonists here, their trajectories intersecting, moving at a slow pace very close to the camera lens. Despite focusing on the same central city locations, the Lambton Quay and Manners Street/Courtenay Place areas, this film, unlike The Maritime City, makes no use of accelerated motion or shots taken from vehicles. Overall, the representation of Wellington city centre life is less stylised, and the general impression conveyed is more naturalistic. A very similar focus on the crossing trajectories of trams, cars and pedestrians in the Lambton Quay area is also a feature of Glimpses of New Zealand. Wellington, New Zealand's Capital City.

Ship transport, for both passengers and freight, also plays an important role in the celebration of Wellington urban (and suburban) mobility. If the suburban beach is a quite popular leisure space for early twentieth-century New Zealanders and Wellingtonians, the sea is essentially a place of work and a means of connection to the outside world. Moreover, Wellington's urban structure made marine suburban transport necessary. For these reasons, the celebration of maritime transport, and, more specifically, the constant depiction of the port of Wellington as a local and international hub, are recurring themes in the majority of Wellington tourism films from the 1920s and 1930s. In Wellington Sunshine Sands, the trans-harbour ferry is the easiest way to reach the northern beach suburbs and the journey of the holidaymakers is followed through three different shots: the first one, taken from the wharf, displays the ferry's slow headway; the second one, a long shot probably taken from another boat, portrays the ferry during the harbour-crossing; the third and last shot dwells upon the landing and the setting down of passengers. Within this film, maritime transport appears to be efficiently integrated with urban vehicle and rail transport; moreover, it is a service accessible by everyone, directly and naturally linked to the egalitarian and democratised ritual of suburban beachgoing.

On the contrary, Deep Harbour The Port of Wellington focuses on the role of Wellington's port as an international transport hub, visually celebrating Wellington Harbour's entrance, its subtitles asserting that "ships from half the world apart converge at the entrance way." Similarly, Around Port Nicholson and The Maritime City focus through aerial shots on the incessant coming and going of ships, freighters and ocean liners: this depiction of chaotic maritime traffic evokes a functioning interconnection of remote New Zealand with the rest of the world. New Zealand is no longer a faraway and isolated country, and it is potentially appealing for both tourists and new settlers.

The representation of Wellington as an efficient and productive urban centre is not only restricted to images of the local urban transport system, but also features scenes taken directly from the local industrial world, adhering to the lively 1920s and 1930s GPO tradition of films dealing with local productive activities. Wellington's textile, food and manufacturing industries are shown in the first half of Around Port Nicholson; within this sound film, a stereotyped representation of Fordist man-machine interaction, the consequent celebration of "modern times" (including, of course, Wellington's and New Zealand's modernity) and a detailed description of industrial automation clearly prevail in the depiction of factory workers, whose faces are barely visible. In fact, human beings and, more particularly, their repeatedly portrayed hands appear to be mere complementary accessories of the automated industrial system. 
However, Wellington's productive hub seems in the 1920s and 1930s to be its port: Wellington is very often depicted as a harbour city. Port activities and dock workers are the protagonists of two GPO films: Deep Harbour: The Port of Wellington and The Maritime City. The former dwells upon the incessant coming and going of ships in the harbour, describing in detail the activity of the signalman and the Harbour Board, depicting in its last part the whalers moored at the waterfront and ready to sail, according to the titles, "off to the white Antarctic"; the latter portrays and visually celebrates the hectic rhythms of port activities such as loading and discharging or ship repair through shots of dock workers in action. Differently from the anonymity of factory workers in Around Port Nicholson, here the dock workers' faces are shown, and a degree of stylization is also observable: port activities are shown through accelerated motion shots that convey a general idea of dynamism. Wellington is, according to both films, a national and international commercial hub where commerce carriers load, as The Maritime City's subtitles state, "for the far off British Isles" and "coastal vessels distribute the cargoes for other New Zealand ports."

The optimistic projection of Wellington towards the future is similarly reflected in a focus on downtown vertical architecture. The tendency to display urban areas by depicting their tall, modern, concrete buildings is particularly evident in Wellington, Capital City of New Zealand and in The Maritime City. Both films provide panoramic views of buildings, lingering on two Wellington urban locations par excellence: Lambton Quay and Courtenay Place. The latter film, in particular, features a tram ride through Lambton Quay, using both static and moving camera shots. The dynamic shots are taken from a tram taking the route of the 1855 shoreline, as highlighted by the inter-titles: "Tall buildings stand where once the foreshore lay." The representation of mobility and the celebration of architectural verticality are combined in this film to convey an overall impression of modernity. More specifically, the dynamic shots portray the slow succession of the facades of Lambton Quay buildings; the static one, taken from a camera placed in the middle of an intersection in a no longer recognizable city location, features two tall modern concrete buildings whose size absorbs much of the viewer's attention. A similar focus on the vertical city risen from the sea is observable in Romantic New Zealand: Lambton Quay once again symbolically represents the hub of urban modernity, and a long take lingers on the facades of tall concrete buildings. Around Port Nicholson provides an unprecedented depiction of Wellington's central business district at night. A fast-paced juxtaposition of quick cuts features neon lights. According to the narrator's voice-over, "outside the cabaret electric signs abound, most of them well known to the citizens." The lights shine on tall vertical buildings and advertise goods, shops and shows: the futuristic city also lives and shines at night. New vertical buildings embody an idea of progress and optimism: as Around Port Nicholson's voice-over states, "splendid office buildings . . . prove that Wellington is progressing at all points."

The representation of central Wellington as the productive, non-residential area of the city is informed by three ideological roots. First, the visual celebration of the energy and dynamism of the capitalistic urban world appears to be consistent with a widespread zeitgeist and its related artistic and cultural expressions. Second, the general impression of modernity and efficiency emerging from Wellington tourism films is linked to tourist and colonial promotion and to the necessity of presenting New Zealand's capital city as a thriving and appealing destination for both tourists and potential settlers. Finally, the role of national publicity in celebrating Wellington's dynamism has to be framed in the context of New Zealand economic downturn that hit the country from 1927 to $1935 .{ }^{42}$ 
Downtown Wellington as it emerges from the analysis of these case studies is a cohesive and functional system whose life is dominated by technology. Modern means of transportation technology - trams, cars, ferries, ships - and modern means of production-manufacturing industries characterised by a Taylorist organization of labour-are the gearwheels of a wellestablished urban mechanism. In the urban space of productivity, human beings-the Wellingtonians - stand like a blurred presence in the background, pedestrians walking on footpaths or crossing streets, tram or ship passengers, car drivers, factory workers intent on their work. Mechanical efficiency and a visual celebration of urban capitalist society and modern architecture prevail in any attempt at social and sociological analysis. In an age characterized in fact by rising unemployment rate, widespread pessimism, and a drop in industrial production, the overall character and tone in representation are mostly nonproblematic, joyful and celebratory, lacking any type of criticism, carefully avoiding the depiction of conflict. ${ }^{43}$

However, the drive for national publicity and colonial promotion overlaps and coexists with further ideological discourses: the focus on efficiency, newness and work opportunities conveyed by some of the analysed tourism films - The Maritime City, Deep Harbour: The Port of Wellington - aims to present the country in the most appealing way to potential European audiences and to new potential settlers. Nevertheless, in these first decades of the twentieth century the cinematic promotion of New Zealand's capital city is limited not only to the celebration of its suburban and central areas. In fact, Wellington's city identity is also built around the representation of its citizens' habits and everyday life.

\section{Wellingtonians are Part of the Picture: A Turning Point in Cinematic Sensibility}

In the years between the 1920s and the 1930s a debate took place in New Zealand involving national publicity, tourism and educational departments and institutions. The nine years that separate the release of two GPO milestones-Glorious New Zealand and Romantic New Zealand-are indeed the period in which a new awareness begins to emerge in terms of the cinematic promotion of the country. In a film production context that relied until the mid-1920s on the representation of local scenic views and natural attractions, the necessity of depicting and representing aspects of the country such as urban life and human and productive activities became more urgent. At the time, a successful silent tourism film like Glorious New Zealand became the benchmark for further promotional cinematic production. This tourism film, circulated first nationwide and then overseas, immediately reached classic status, meeting with an enthusiastic reception. ${ }^{44}$ It was described as a "scenic classic" whose role was to place New Zealand "before the world as a tourist resort"; it was essentially a scenic film, focusing on the most important scenic attractions, and representing "the cream of two years of cinematographic effort." ${ }^{25}$ This first GPO success is characterised by a traditional approach in terms of New Zealand's representation. Indeed, according to the film's inter-titles, New Zealand offers a "varied and wonderful scenery" and "a never ending panorama of scenic gems."

In the early 1930s, talkies quickly spread worldwide, and a debate over the production of a new, technologically updated tourism film dealing in more detail with New Zealand as a whole suddenly ignited. A successor film to Glorious New Zealand was proposed, that would focus more thoroughly on non-scenic aspects and, unlike its predecessor, would be primarily conceived and made for overseas audiences. According to the intentions of the general manager of Filmcraft Ltd, R. W. Fenton, it would be "a feature length film covering the whole of the Dominion." 46 The focus would shift from the celebration of local scenic attractions to the depiction of the productive world. Primary and manufacturing industries would take the lion's 
share. In an unsuccessful attempt at fundraising, the secretary of industries and commerce and general manager of the Department of Tourist and Health Resorts and Publicity, George Clinkard, wrote to the secretary of the New Zealand Dairy Produce Board stating that in this new film "each of the dairying, pastoral, fruit and honey industries would be well featured." 47 In another letter addressed to the New Zealand Railways publicity manager, he presented this new promotional cinematic project as follows:

As you are aware, some years ago a similar film was released throughout the Dominion under the title of "Glorious New Zealand" and no doubt helped to stimulate the tourist traffic. The new film will be in sound and will be shown abroad as well as locally and will certainly be one of the biggest advertising schemes ever launched. The film will include scenery, sport, industries and items of general interest. ${ }^{48}$

He also described his ideas for this new film in a letter addressed to the director of the Education Department: "The film will include the best of our scenery, sporting items, principal cities, primary industries, bird life, public services, educational institutions and items of general interest." 49 The correspondence between Clinkard and the New Zealand Tourist League highlights even more clearly the terms of the debate and the possible changes and shifts in terms of themes and style. ${ }^{50}$ As Clinkard states in that letter, "we shall be able to give a fairly comprehensive view to overseas people of what New Zealand is to-day." dominated by the representation of New Zealand as a scenic playground and sporting paradise, the presence of subjects such as industry, transport, educational institutions, cities, urban life and city people was eventually legitimised and even desired in order to provide international viewers with a more thorough representation of the country. Although still very relevant, scenic views became just one of the many aspects New Zealand intended to promote abroad.

This new GPO promotional film, called Romantic New Zealand, was finally released on 25 May 1934 at Dunedin's Grand Theatre and soon met with audience and critical acclaim, especially nationwide and in Australia, matching Clinkard's high expectations. ${ }^{52}$ In his words to the president of the Dunedin Chamber of Commerce, Romantic New Zealand "when shown abroad will be a wonderful advertisement for our country." ${ }^{53}$ New Zealand newspaper reviews were also enthusiastic. In a description by The Evening Post, "it is a picture from which one can scarcely choose a portion for special mention, for it deals very comprehensively with the Dominion from practically every point of view." Moreover, "the main cities are depicted with a wealth of interesting detail"; The Dominion Post highlights its success in Perth, Sydney and Great Britain. ${ }^{54}$ Clinkard, writing to the editor of The Waikato Times, could not hide his satisfaction for the film's positive reception, that "is meeting with such success" and "looks like realising its main object, the attraction of increasing numbers of visitors to the unrivalled attractions of the Dominion." 55

This film provides a wide overview of contemporary New Zealand, dealing with scenic tourist attractions, the national economic and industrial world, and scenes taken from Māori life; main urban areas play a very important role here. Auckland's impressive demographic growth is on display; the most populous New Zealand city, with its traffic and modern architecture, embodies, according to the voice-over, the jump from "savagery to civilization." Similarly, the Wellington central business district skyline is celebrated; more importantly, the two most important New Zealand cities in common offer suburban beaches, the ritual of suburban beachgoing and a related suburban lifestyle. Unlike Glorious New Zealand's urban representation, leisure time and lifestyle are now an integral part of the picture. 
While it is partially true, as Hillyer has noted, that the depiction of the human element in GPO films was generally infrequent, mostly stereotyped and very often limited to the representation of scenes taken from the manufacturing sphere, the tourism films of the 1920s and 1930s featuring Wellington linger long over the life of Wellingtonians. ${ }^{56}$

The depiction of Wellingtonians in their work and leisure time challenges a deep-rooted notion related to early New Zealand film production. As Dennis notes, in the 1920s, the GPO directive was to avoid the representation of New Zealanders since they could have been "dated by changes in fashion." ${ }^{57}$ However, the late 1920s and early 1930s show a reversal which contradicts the famous British theorist and documentarist John Grierson's words about the representation of New Zealand in national film production. New Zealand was seen, in his words, "as a mere tourist resort plus a butter factory." Wellington Capital City of New Zealand and tourism/promotional films from the late 1920s and early 1930s evidences this shift. The latter, as well as giving the usual conventional representation of the most famous urban tourist landmarks, is also characterised by a focus on Wellingtonians, their life and their habits. If the scenes taken from industry that feature in Around Port Nicholson evoke a contemporary tradition of New Zealand films mainly focused on working activities and on the depiction and description of automation as a symbol of modernity and productivity, the scenes portraying the port of Wellington and its workers are connected to the celebration of a specifically local and distinctive character: the capital city of New Zealand, in tourism films from the 1920s and 1930s, is often represented and described as a port city. In films such as Deep Harbour: The Port of Wellington and The Maritime City dock workers and shipbuilders, different to factory workers in Around Port Nicholson, are entirely and extensively depicted at work. Their importance lies in their role: they facilitate the trade and exchange of goods and the circulation of people, linking the country to the rest of the world and obscuring its sense of geographical remoteness and isolation.

If, as previously pointed out, leisure time for early twentieth-century Wellingtonians is closely linked to the ritual of beachgoing, other tourist films provide further insights into their leisure preferences. For instance, Around Port Nicholson (1934) features the first cinematic representation of Wellington nightlife. Young men and women are portrayed during a cabaret show: for the first time, Wellingtonians' faces are depicted through close ups and medium close ups. Both the audience's and the jazz musicians' amused expressions are the protagonists of the video. The whole sequence has a hectic pace: it starts by focusing on men and women in the audience, it then briefly depicts musicians playing, and finally, with a shot from above, represents dancers performing on stage. Accelerated motion conveys an impression of energy and dynamism.

Nine years separate Wellington Capital City of New Zealand (1925) and Around Port Nicholson (1934), the latter thematically and stylistically innovative; the same nine years also separate Glorious New Zealand, a collection of scenic gems, and Romantic New Zealand, a film providing a remarkably more complex representation of the capital city of New Zealand.

\section{Conclusions}

Through the use of textual analysis, archival research and an interdisciplinary approach, this paper adds new ideas to the existing scholarly discourse on New Zealand's early film production. It first of all stressed the recurring presence and importance of suburban space in early national tourism film production, with a particular focus on the Wellington beach as the suburban playground par excellence. In doing so, it questioned the current dominant 
interpretation of the New Zealand beach as a wild, untamed, extra-urban space. Second, it emphasized the centrality of the representation of suburban sprawl as a recurring visual pattern and a promotional tool employed to convey to domestic and international audiences images of progress and economic growth. Third, through the textual analysis of selected case studies, it noted how the celebration of Wellington's urban modernity and dynamism was rooted in preexisting visual and ideological tropes and in the necessity to spread a non-problematic and optimistic message in a time of economic recession. Finally, through the examination of archival documents, and by providing evidence of the behind-the-scenes institutional debate about New Zealand tourism and colonial promotion, it questioned and partially contradicted a deeply rooted belief in New Zealand film studies, that is, the lack of interest in human representation and the consequent absence of human beings in early film production. More broadly, it stressed how the cinematic representation of Wellington's urban and suburban landscapes in the early decades of the twentieth century was a multi-layered process driven and informed by the simultaneous intertwining of tourism promotion, national publicity and colonial agenda.

\footnotetext{
${ }^{1}$ Margaret McClure, "Creating a Tourism Industry: The Backdrop for Tourism Publicity," in Selling the Dream: The Art of Early New Zealand Tourism, ed. Peter Alsop, Gary Stewart and Dave Bamford (Nelson: Potton and Burton, 2012), 20-28; Warren Feeney, "High Art: The Fine Art of Commercial Art," in Selling the Dream: The Art of Early New Zealand Tourism, ed. Peter Alsop, Gary Stewart and Dave Bamford (Nelson: Potton and Burton, 2012), 70-76.

${ }^{2}$ James Taylor, Consuming Identity: Modernity and Tourism in New Zealand (Auckland: Department of Anthropology-The University of Auckland, 1998), 11.

${ }^{3}$ In 1923, New Zealand government involvement in filmmaking became systematic. The GPO was originally a publicity office attached to the Department of Internal Affairs that mostly produced tourism films for domestic and overseas tourism promotion. From 1941 to 1990 the National Film Unit became the government-led institution in charge of national publicity.

${ }^{4}$ Alfio Leotta, Touring the Screen (Bristol: Intellect, 2011), 16.

${ }^{5}$ Feeney, "High Art."

${ }^{6}$ Peter Gibbons, "Cultural Colonization and National Identity," New Zealand Journal of History 36, no. 1 (2002): 9.

${ }^{7}$ Mary Louise Pratt, Imperial Eyes: Travel Writing and Transculturation (London: Routledge, 1992).

${ }^{8}$ Giselle Byrnes, Boundary Makers: Land Surveying and the Colonisation of New Zealand

(Wellington: Bridget Williams Books, 2002), 8, 41.

${ }^{9}$ Claudia Bell and John Lyall, Putting our Town on a Map (Harper Collins NZ, Glenfield, 1995);

Taylor, Consuming Identity.

${ }^{10}$ Barry Hancox, "Lasting Images: Photography and Tourism Publicity," in Selling the Dream: The Art of Early New Zealand Tourism, ed. Peter Alsop, Gary Stewart and Dave Bamford (Nelson: Potton and Burton, 2012), 76-82; Peter Ireland, "Photography_Early Photography, 1840-1880s," Te AraThe Encyclopedia of New Zealand, last modified 22 October 2014, http://www.TeAra.govt.nz/en/photography/page-1.

${ }^{11}$ Annie Goldson, Memory, Landscape, Dad and Me (Wellington: Victoria University of Wellington, 2006), 15.

${ }^{12}$ See John Urry, Consuming Places (London: Sage, 1995).

${ }^{13}$ See Simon Schama, Landscape and Memory (New York: Harper and Collins, 1995).

${ }^{14}$ See Kenneth Olwig, "Natural" Landscapes in the Representation of National Identity (London:

Routledge, 2008); also see David Eggleton and Craig Potton, Here on Earth: The Landscape in New Zealand Literature (Nelson: Craig Potton 1999).

${ }^{15}$ Bell and Lyall, Putting our Town on a Map.
} 
${ }^{16}$ Benedict Anderson, Imagined Communities: Reflection on the Origin and Spread of National. (London: Verso, 1983), 113-14.

${ }^{17}$ Minette Hillyer, "We Calmly and Adventurously Go Travelling" (master's thesis, University of Auckland, 1997); Glorious New Zealand, directed by Arthur Messenger (New Zealand: Government Publicity Office, 1925), film; Romantic New Zealand, directed by Cyril Morton (New Zealand: Government Publicity Office, 1934), film.

${ }^{18}$ Leotta, Touring the Screen, 20.

${ }^{19}$ Diego Bonelli, "This is Wellington. The Representation of New Zealand Tourism Film from 1912 to 2017" (PhD thesis, Victoria University of Wellington, 2018).

${ }^{20}$ Out of 347 promotional films made by this government-driven institution between 1921 and 1941, 102 have survived and are available for viewing; six of them focus on Wellington.

${ }^{21}$ Wellington and Assorted Scenes, directed by Sydney Benjamin Taylor (New Zealand, Department of Agriculture, Industries and Commerce, 1912), film; Wellington Capital City of New Zealand (New Zealand: Government Publicity Office, 1925), film; Deep Harbour: The Port of Wellington (New Zealand: Government Publicity Office, 1929). Film; Wellington Sunshine Sands (New Zealand: Government Publicity Office, 1930), film; The Maritime City (New Zealand: Government Publicity Office, 1930), film; Romantic New Zealand, directed by Cyril Morton (New Zealand: Government Publicity Office, 1934), film; Around Port Nicholson (New Zealand: Sound Film Production, 1934), film; Glimpses of New Zealand: Wellington New Zealand's Capital City (New Zealand: Government Publicity Office, 1935), film.

${ }^{22}$ Margaret McClure, The Wonder Country: Making New Zealand Tourism (Auckland: Auckland University Press, 2004).

${ }^{23}$ Lee Davidson, "Publicising Peaks: Early Promotion of Mountain Tourism," in Selling the Dream: The Art of Early New Zealand Tourism, ed. Peter Alsop, Gary Stewart and Dave Bamford (Nelson: Potton and Burton, 2012), 56-62.

${ }^{24}$ The circulation and screening of New Zealand tourism films and tourist material within New Zealand itself, Australia and Europe was a common, consolidated and widespread practice in the third and fourth decade of the last century. Indeed, The Evening Post dwells, in a 1928 article, upon the success of a GPO film - the title of which is not mentioned - screened at Sydney's town hall, able to attract "more than 3000 spectators" ("New Zealand Publicity. Interesting Sydney Folk," The Evening Post, 15 December 1928 [vol. 106, issue 132], 10,

https://paperspast.natlib.govt.nz/newspapers/EP19281215.2.78.6); the same newspaper, in a 1925 article, describes the distribution of 2000 enlarged photographs of New Zealand scenes in London and in a number of schools all around Britain ("New Zealand Scenes," The Evening Post, 4 November 1925 [vol. 110, issue 109], 2, https://paperspast.natlib.govt.nz/newspapers/EP19251104.2.5); another newspaper article, in 1926, focuses on the circulation and screening of films and lantern lectures on New Zealand, over 600 lectures screened in different areas of Britain, in locations such as military centres, populous provincial towns and in schools of varying grades ("Publicity in Europe. Films and Lectures in New Zealand. Useful Propaganda. British Empire Products," The Evening Post, 12 May 1926 [vol. 111, issue 102], 3, https://paperspast.natlib.govt.nz/newspapers/EP19260512.2.8).

${ }^{25}$ McClure, The Wonder Country.

${ }^{26}$ Dominic Alessio, "Coloured Views: Images of the New Zealand City and Town, 1880-1930" (PhD thesis, Victoria University of Wellington, 1992). As Alessio points out, the newly born Department of Tourist and Health Resorts "used a host of techniques to promote New Zealand, including: the creation of a photographic and film section to show everyday scenes of New Zealand; ... the presentation of lantern slides exhibitions with shots of cities, the Māori and New Zealand's natural wonders; taking out newspaper advertisements to influence foreign travellers to choose New Zealand as their holiday destination; and the publication of numerous pamphlets summarizing sites of interest" (24-25).

28 "More Publicity Advertising. New Zealand Chamber of Commerce Ideas Placed before Prime Minister," The Evening Post, 11 September 1924 (vol. 52, issue 127), p. 5. National Library of New Zealand, Wellington, New Zealand.

Journal of New Zealand Studies NS30 (2020), 56-71. https://doi.org/10.26686/jnzs.v0iNS30.6498 
${ }^{29}$ Taylor, Consuming Identity.

${ }^{30}$ M. Derby, "Selling Māoriland: Māori at the Centre of Tourism Publicity," in Selling the Dream: The Art of Early New Zealand Tourism, ed. Peter Alsop, Gary Stewart and Dave Bamford (Nelson: Potton and Burton, 2012), 48-56. An analysis of the surviving GPO tourism film higlights how these Māori-themed films are very often related to the promotion of the Rotorua district, the so-called "Thermal Wonderland," focusing in particular on the Māori village of Whakarewarewa. Normally such films intend to show how modern tourist facilities coexist with traditional Māori art, crafts and typical architecture, songs and typical dances, scenes of everyday life and traditional costumes against a background of hot pools, boiling lakes and erupting geysers. See The Mãori As He Was (New Zealand: Government Publicity Office, 1928), film; Valley of Enchantments: Rotorua's Geyser Land (New Zealand: Government Publicity Office, 1930), film; Whakarewarewa (New Zealand: Government Publicity Office, 1927), film; and Holiday Haunts: Rotorua, New Zealand (New Zealand: Government Publicity Office, 1935), film.

${ }^{31}$ See Beautiful Avon, Waterway of Christchurch (New Zealand: Government Publicity Office, 1928), film. This film features large suburban detached houses with their "quarter acre paradise"; or see The Out of Doors: The Environs of Auckland (New Zealand: Government Publicity Office, 1929), film. This film visually celebrates the sprawl of Auckland's suburban residential areas through bird's-eye view and aerial shots; or see Down South (New Zealand: Government Publicity Office, 1928), film; or, again, see Glimpses of New Zealand: Round About Dunedin (New Zealand: Government Publicity Office, 1930), film. This film feature bird's-eye views of Dunedin's coastal suburbs.

${ }^{32}$ See the above-mentioned The Out of Doors or Pleasure Island. Kawau Island. Auckland (New Zealand: Government Publicity Office, 1929), film. Also see the above mentioned Romantic New Zealand (1934), that focuses on Auckland's coastal areas, suburban beaches and - more generallyon Auckland's surroundings as an integral part of Auckland's tourist experience. Similarly, in the above-mentioned Glimpses of New Zealand, Dunedin's coastal suburbs and local suburban beachgoing are in the foreground, while the depiction of Napier's beaches and coastal areas is the visual and thematic backbone of Know New Zealand First no.151: Sunny Napier, the Brighton of New Zealand (New Zealand: Government Publicity Office, 1929), film.

${ }^{33}$ See City of Plains (New Zealand: Government Publicity Office, 1930), film. This film focuses on Christchurch's city centre and on the hectic coming and going of bikes, cars, trams and pedestrians. Similarly, in Dunedin City (New Zealand: Government Publicity Office, 1926), film, the depiction of the city is characterised by a focus on the incessant flow of vehicle and pedestrian traffic, while Glorious New Zealand (New Zealand: Government Publicity Office, 1925), film, features views of Auckland's Queen Street traffic.

${ }^{34}$ See on this topic Damian Collins and Robin Kearns, Ambiguous Landscapes: Sun, Risk and Recreation on New Zealand Beaches (Allison Williams, Aldershot, 2007); Caroline Daley, Leisure and Pleasure: Reshaping and Revealing the New Zealand Body 1900-1960 (Auckland University Press, Auckland, 2003); Douglas Lloyd Jenkins, Beach Life (Penguin Books New Zealand, Auckland, 2016).

${ }^{35}$ Richard Coldicutt, "The Beach as an Erogenous Zone: Figuring Through Painting" (PhD diss., Curtin University, 2014); Robert Preston-White, "The Beach as a Liminal Space," in A Companion to Tourism, ed. Colin Michael Hall, Allan Lew and Alan Williams (Hoboken: Wiley-Blackwell, 2008), 349-59; Sarah Brown, Stacey Fox, and Alison Jacquet, "On the Beach: Liminal Spaces in Historical and Cultural Contexts," Limina: A Journal of Historical and Cultural Studies, special edition (2007): $1-3$.

${ }^{36}$ Rob Shields, Places on the Margin: Alternative Geographies of Modernity (London: Routledge, 1991), 84.

${ }^{37}$ Steve Matthewman, "More than Sand: Theorizing the Beach," in Cultural Studies in Aotearoa: Identity, Space and Place, ed. Claudia Bell and Steve Matthewman (Melbourne: Oxford University Press, 2004), 36.

${ }^{38}$ Stephen Turner, "Settlement as Forgetting," in Quicksands: Foundational Histories in Australia and Aotearoa New Zealand, ed. Klaus Neumann, Nicholas Thomas, and Hilary Ericksen (Sydney: University of New South Wales Press, 1999), 31.

Journal of New Zealand Studies NS30 (2020), 56-71. https://doi.org/10.26686/jnzs.v0iNS30.6498 
${ }^{39}$ Leotta, Touring the Screen, 87; The Piano, directed by Jane Campion, performed by Holly Hunter and Harvey Keitel (New Zealand, Australia, and France: CiBy 2000, Jan Chapman Productions, Australian Film Commission, The New South Wales Film and Television Office, 1993), film.

${ }^{40}$ Matthewman, "More than Sand."

${ }^{41}$ Raymond Williams, Culture and Society (London, Hogarth Press: 1987).

${ }^{42}$ The Great Depression had repercussions for New Zealand immigration policies: more people left the country than arrived. See Jock Phillips, "History of Immigration," Te Ara-The Encyclopaedia of New Zealand, last modified 1 August 2015, http://www.TeAra.govt.nz/en/history-ofimmigration/print.

${ }^{43}$ See James Belich, Paradise Reforged: A History of the New Zealanders (Honolulu, University of Hawai'i Press, 2001), 254-59; Mark Derby, "Strikes and Labour Disputes-Wars, Depression and First Labour Government," Te Ara-The Encyclopaedia of New Zealand, last modified 1 March 2016, https://teara.govt.nz/en/strikes-and-labour-disputes/page-6; Michael King, The Penguin History of New Zealand (Rosedale, Penguin Group New Zealand: 2003), 416-17.

${ }^{44}$ As reported in The Evening Post, "The Publicity Department has received many congratulatory messages in regard to the film, which is generally acknowledged as a great tribute to New Zealand's scenic wonders. Among the messages received were felicitations from the Prime Minister, the Minister of Education and Mr. T. M. Wilford," ("Glorious New Zealand," The Evening Post, 20 October 1925 [volume 60, issue 96], 10, National Library of New Zealand.

45 "Glorious New Zealand," The Evening Post, 10.

${ }^{46}$ R. W. Fenton to the General Manager of Tourist and Publicity Departments, 7 January 1932, R21485748, box 193, record 49/3, Archives New Zealand, Wellington. Filmcraft Ltd were advertising and motion picture studios set up in Miramar in 1928 to process GPO films.

${ }^{47}$ G. W. Clinkard to the Secretary of New Zealand Dairy Producers Board, 7 December 1931, R21485748, box 193, record 49/3, Archives New Zealand, Wellington.

${ }^{48}$ G. W. Clinkard to The Publicity Manager of New Zealand Railways, 19 January, 1932, R21485748, box 193, record 49/3, Archives New Zealand, Wellington.

${ }^{49}$ G. W. Clinkard to The Director of Education Department, 21 January 1932, R21485748, box 193, record 49/3, Archives New Zealand, Wellington.

${ }^{50}$ G. W. Clinkard to the President of New Zealand Tourist League, 7 September 1932, R21485748, box 193, record 49/3, Archives New Zealand, Wellington. According to Clinkard's plan, the film would "consist in large part of scenic views but will deal also with the photographically acceptable features of our main primary industries, our city life, transport, resources, etc. The film is therefore not of exactly the same character as Glorious New Zealand, which was based purely upon the scenic values."

${ }^{51}$ G. W. Clinkard to the President of New Zealand Tourist League, 7 September 1932, R21485748, box 193, record 49/3, Archives New Zealand, Wellington.

52 "Romantic New Zealand Opening at the State Centre," The Evening Post, 12 July 1934 (volume 68, issue 10), 5, National Library of New Zealand.

${ }^{53}$ G. W. Clinkard to the President of Dunedin Chamber of Commerce, 28 April 1934, R21485750, box 193, record 49/3, Archives New Zealand, Wellington.

54 "Romantic New Zealand Opening at the State Centre," The Evening Post; "Romantic New Zealand," The Dominion Post, 1935; both R21485750, box 193, Archives New Zealand, Wellington.

${ }^{55}$ G. W. Clinkard to the Managing Director of the Waikato Times, 6 May 1935, R21485750, box 193, record 49/3, Archives New Zealand, Wellington.

${ }^{56}$ Hillyer, "We Calmly and Adventurously Go Travelling."

${ }^{57}$ Jonathan Dennis and Paolo Cherchi Usai, eds., Aotearoa and the Sentimental Strine: Making Films in Australia and New Zealand in the Silent Period. (Pordenone: Le Giornate Del Cinema Muto, 1993), 9.

${ }^{58}$ John Grierson, "The Face of a New Zealander," in The "Tin Shed": The Origins of the National Film Unit, ed. Jonathan Dennis (Wellington: New Zealand Film Archive, 1981), 21. 